DOI: 10.12731/2227-930X-2016-1-38-56

\title{
PROCESS APPROACH TO CULTURAL POLICY IN THE REGIONAL ASPECT
}

\section{Lavryshsheva M., Kozlova L.}

One of the most important social and political functions of any state is the cultural policy designed to regulate the inner life of civil society. Cultural factors are decisive in the creation of a harmonious society, but also in enhancing the intellectual and spiritual potential of the human capital which is the lead factor in the development of any state.

Characteristics of cultural policy, as a process, i.e. procedural approach, allows us to see the specific aspects of interaction of subjects over the governmental authorities. However, due to the fact, that in its scale cultural process is the same as political environment of the state, some scientists identify it either with politics in general or with the totality of the shares of behavioral government entities, change their status and influence. Supporters of the institutional approach associates the cultural political process with the functioning and the transformation of the government institutionbl, based on a set of the political system reactions on the environmental challenges. As we speak in the current economic conditions in Ukraine is actual the development of anti-crisis measures for the rehabilitation and development of the conceptual approach of cultural policies in the region. As such, the obvious is the development of a measures set by all courses of the plan, that will mutualize the key goals, objectives and tools into a uniform system of measures. This plan should provide the combined model in the region and provide a transition to the zonal management principle of the transition period. In the plan it is also should be provided institutional support for the proposed measures, namely the mechanisms 
of technological and socio-cultural issues implementation in range of the cultural policy of the society [1, p.18].

Keywords: cultural policy; political process; political actor; political institution.

\section{Introduction}

Among culture and politics, there is no less close relationship than that between culture and economy. To grow and be passed from generation to generation, culture needs to be supported by the political authorities and the state. In turn, the political power is in need of the culture to be approved and supported. One can say that culture and politics are experiencing a mutual attraction and mutual need for each other. Politicians have the special interest in art, because it composes the core and the highest expression of culture.

The state is the main policy instrument and is the same to culture. It is the part of the cultural management system, and occupies in this system the highest level. The other main management levels are the regional and municipal. Modern form of state participation in culture is a cultural policy, which is the coordination and control of all cultural activities related to the maintenance and operation of historical and cultural heritage, ensuring equal access for all to culture, the support of art and all kinds of art, as well as, the cultural presence in other countries, and the influence on them. The state provides financial (budget), administrative, legal and moral support for all types of cultural activities. Cultural functions of the state are a logical response to natural, necessary and extremely important needs of people and society. Cultural activity is the content of cultural policy.

The problems of state cultural policy as a factor of the society reform under political process specifics were studying by Astafev O.N., Balakshin A.S., Vostryakov A.E., Drozhzhina S.V., Izhikova N.V., Karpuhin O.I., Malimon V.M., Michailovich V.A. and etc. 
It should be noted that the above-mentioned authors have dealt with issues of cultural policy at the central level of the state. However, some issues are not covered in these studies, it wasn't also sufficiently studied the special aspects of stabilization and implementation of cultural policies at local region in the transition level, the evaluation of political process applicability, the local transformations of political activity.

\section{The political process structure}

Some researchers consider the political process is a natural phenomenon that has an irrational character and dependent of the will and character of the people above all political leaders. The significance of random phenomena and events is particularly noticeable at the micro level. However, the general nature of politics and cultural policies as well as institutional and other contexts of the activity (rules, certain forms and modes of behavior, traditions and the dominant values, etc.) make the political process as normalized and comprehend. It is a logical unfolding sequence of interactions between people.

Thus, the political process is integral phenomenon amenable to structuring and scientific analysis. Unpredictability and seemingly inexplicable of certain events should be seen mainly as a consequence of the imperfection of scientific apparatus and tools [2, c. 45].

The political process structure can be described by the interaction analysis between the various political actors, as well as through the identification of dynamics (the main phases of the political process, the change of these phases, and so on) of this phenomenon. It is also important the factors clarification influenced the political process. Thus, the policy process structure can be defined as set of interactions between actors and their logical sequence (political process "plot"). Each individual policy process has its own structure and therefore their own "plot". Actors the totality of their interactions, sequence or the plot dynamics, the time units, as well as factors affecting the political process, usually are called the political process parameters, who 
are linked to the complexity of the concept of the process approach to the cultural policy of the society [3, p. 34].

The main factors of the political process are political systems, political institutions (government, civil society, political parties, etc.), organized and unorganized groups of people and individuals.

The Political institute is reproducible over time a set of rules and regulations, as well as institutional capacity, organize political relations in a particular area of political life [4, p. 62].

The main governance institution and one of the main political process actor is the state. Another important actor in the political process is civil society, which is also considered as a political institution. It should be noted that the state and civil society as political actors are generated in Europe and the US in new time period under the influence of modernization changes [5]. Since that time, it is formed the main government institution in society, which has a monopoly on coercive violence in a specific territory and it is named the state. At the same time, under the influence of this process it is formed the civil society, called the antithesis of the state. Civil society interacts with the state through cultural policies.

Smaller actors of the political process are the parties, interest groups, individuals and groups of people [6, p. 112].

Individuals and groups could engage in politics, not only in the institutional form, for example, vote in the elections, but also in the non-institutional forms, in the form of spontaneous mass protests.

People differ in varying degrees of activity in the cultural policy. The number of are not very active, but in general, are involved in most of the processes institutionalized. Some of just sit on the sidelines, not only by taking an active part in political life, but not participating in the elections, not reading newspapers, etc. Others of, however, this is usually a minority of citizens, on the other hand, take an active part in political life and to take into account the cultural policy society specificity as a whole. 
To achieve group goals, individuals can create special groups, varying degrees of institutionalization of the random group formed at the meeting to a highly organized, which have the permanent character and valid according to the strict rules of the group's interests. The degree of political activities institutionalization depends not only the achievement of specific goals (as a rule, it is the more efficient than the higher the institutionalization degree), and reproducibility, repeatability, regularity of any political relations and their strengthening in the rules and regulations [7].

We will carry out a more detailed analysis of the political process from the point of view of regional development programs under the review of the cultural policy features.

In the analysis of the political process it should be taken into account the nature of the interaction between its subjects. It is important to note that the nature of the interaction depends on the scale of the political process and actors. In particular, the nature of the interaction between the political system and the environment will be determined by the level of the evolutionary development of the system and the environment, such as the degree of internal differentiation. At the same time, the nature of the interaction between actors, in particular between a citizen and a certain party, will be determined by other parameters: institutional conditions, the peculiarities of the party development, the party locate on the political system, the social and psychological characteristics of the individual, etc. In general, abstracting of the political processes and actors specifics, it is often described the nature of the interaction between actors in terms of confrontation, neutrality, compromise, union, consensus.

Two groups of factors of the political process can be identified: the "internal" and "external". By "external" refer environment (socio-economic, socio-cultural and other conditions) and its impact, the system, but "external" for the political process, political circumstances, such as the terms and conditions of the political game, "external" 
political events etc. By "internal" it may be include parameters such as the characteristics of the actors, their goals and intentions, the distribution of power resources, the logic and the "plot structure" of the political process [8].

An important parameter of the political process is its division into stages. Political processes of various kinds provide an example of a different stages combination. Diverse and uniformity of processes leads to the fact that highlight any steps that are common to all types of processes, is quite difficult. The various stages are the stages of the functioning of the political system, the electoral process or the process of creation and functioning of political parties. Therefore, the selection of specific steps appropriate in relation to certain types of political processes (Fig. 1).

The majority of the political actors interactions relate to the exercise of public power. For this reason, the process it is particularly great importance the adoption and implementation of political decisions. The analysis of this process is one of the most popular topics of foreign political science. Among researchers there is no consensus on the number and content of its stages.

Summarizing the different approaches, it can be associated with the following main phases:

- formulation of the problem (collecting the necessary information about the existing problems, public inquiries and possible solutions, the definition of primary and secondary problems);

- the formation of alternative solutions;

- comparative analysis and selection of the most effective solutions;

- the formation of public decision and its legitimation (through the adoption of laws, voting and so on.);

- implementation of the taken decisions;

- monitoring of the implementation and realization of "feedback". 


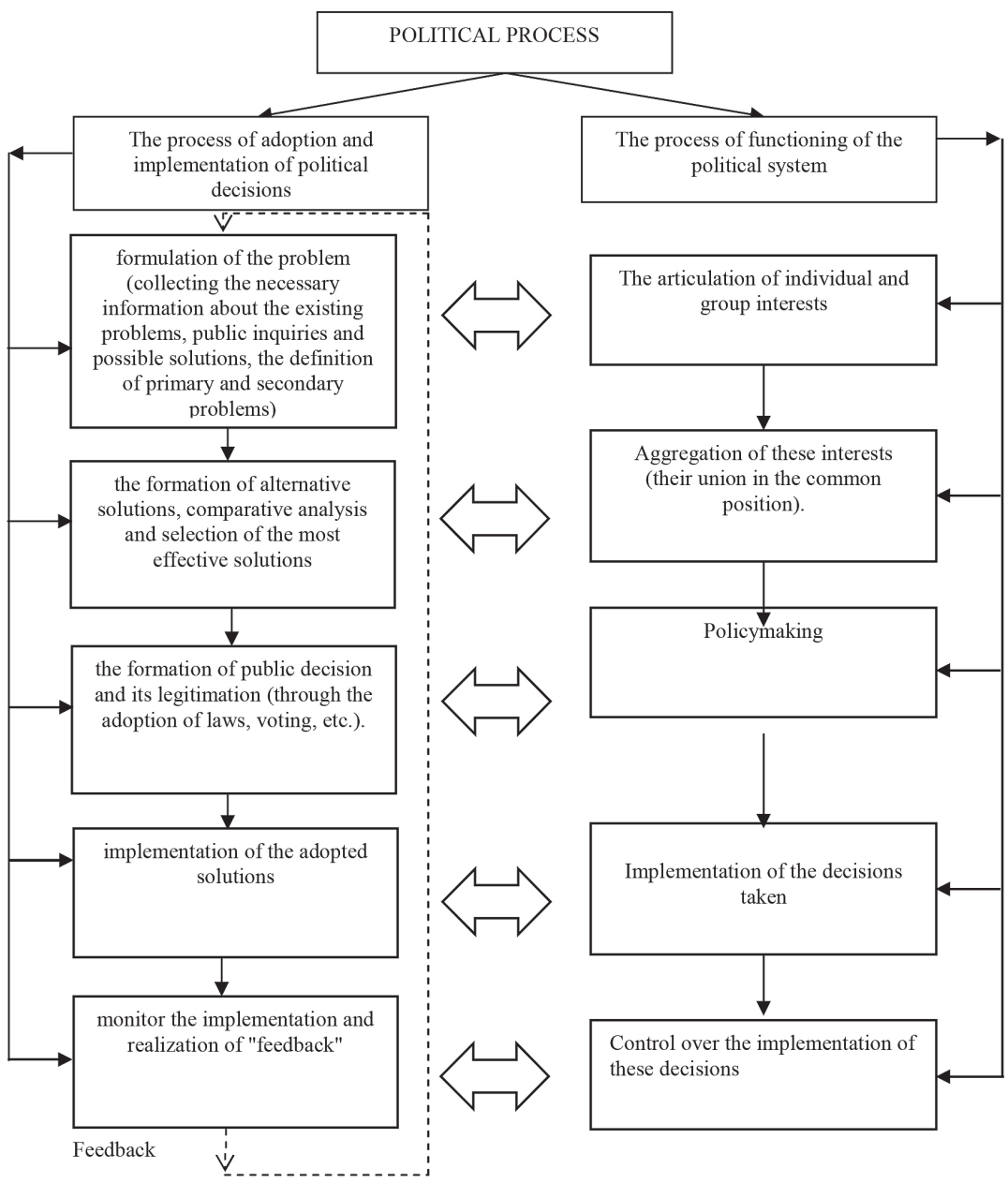

Fig. 1. Comparative characteristics of the political process

If we turn to the process of political system functioning, then a set of steps will be materially different, because it will take into account the interaction with the environment of the system. However, in science it is well known the attempts to highlight the main stages of this process it also focused on the adoption and implementation 
of management decisions. "A classic set " of phase is to identify the main stages:

1. The articulation of individual and group interests.

2. Aggregation of these interests (their union in the common position).

3. Policymaking.

4. Implementation of the decisions taken.

5. Control over the execution of these decisions.

It should be noted that this model represents only one type of the political process and can not be regarded as universal.

\section{Political changes and their types}

Political changes are a specific type of social change related primarily to changes in the mechanism of regulation of the power of society. The political system under the influence of qualitative changes in the social environment is constantly in motion and development. In fact, there are not two identical states of the same political system. Consequently, political changes are transforming institutional structures, processes and goals that affect the distribution and administration of power management to developing society [9]. Political changes can occur either by adapting the system to the new requirements of the social environment, or by changing a system that is unable to maintain himself and the other. As part of the same society the political changes, that have a broad and lasting impact on society, can be described as a revolution. Revolution is a radical type of political changes, which resulted in the aborted old political tradition and the new political system of play.

Revolution as the type of policy changes should be distinguished from the insurrection. Last one is a sudden and unconstitutional change of the ruling elite, which is itself does not involve any profound changes in social relations. Revolutions and insurrections do not represent the most common type of political changes, though always cause perma- 
nent public interest [10, p. 89]. The most common type of change is a system adapting to new requirements or changes in the social environment. Such changes occur constantly in any well-functioning political system. They may be associated with the redistribution of political power under this society, with the introduction of constitutional changes in the power relations structure under the same political system, etc.

Conscious, systemic changes that have a broad and lasting impact on society, but reproduce the former political system, can be defined as reform. The reforms led to a change in the state of social and political relations under the existing political system. Therefore, the most important characteristic of the political process is the method or mode of political authority actualization (the reproduction of the political system).

The reform of political relations, changing the constitutional and legal methods and means of political authority realization under one political system and creates a certain political regime. Therefore, the concept of political regime characterizes the political process from the point of view of functioning and self-reproduction of a particular political system of this society.

Depending on the choice of fixed and variable characteristics of the political changes in the political science has developed two approaches: contextual and institutionalist. The first approach is based on the idea of the primary role of the social context, the social environment, socio-economic, socio-cultural conditioning of political and institutional change (Aron, R. Dahl, S. Lipset). The second approach focuses on the internal institutional structure of the political process. The nature and success of social change depends primarily on the level of political institutionalization. There are a variety of hesitation social environment, economic crises and public performances, but ultimately depends on the efficiency and adaptive response of institutional mechanisms to manage society, to maintain the stability of it (S. Huntington, T. Skolpol, D. March) [11, p. 43]. 
The variety of sources and forms of political change is expressed in certain ways to the existence of political phenomena, namely, the operation, development, and decline.

The functioning of political phenomena does not display relationships, behaviors of individuals or the execution of state power institutions of their direct functions beyond the established baseline values. For example, at the level of society as a whole is a way to maintain the current political system, the reproduction of the balance of power that reflects their basic relations, production of the main functions of structures and institutions, forms of cooperation between the elite and the electorate, political parties and local authorities, etc. In this way, changes in tradition and continuity have undisputed precedence over any innovations [12, p. 15].

The second method of political change is the development. He characterizes such modifications of basic parameters of political phenomena, which suggest further positive evolution of the latter. For example, in the scale of social development can mean such a change, in which the policy of the state is displayed on the level, which allows the authorities to respond adequately to the challenges of time, to manage public relations, to provide for the social demands of the population. This pattern of political change promotes compliance with the political system changes in other spheres of public life, improve its ability to use flexible strategies and technologies ruling based on the complexity of interests of different social groups and citizens [12, p. 16].

Finally, the third kind of change is a decline that characterizes such a process of transformation of the existing basic forms and relationships, which assumes a negative perspective of the evolution of political events. In the opinion of Struve, the decline is «regressive metamorphosis» policy. The decline political changes characterized by an increase in entropy, and the predominance of the centrifugal tendencies of integration. Therefore, the decline essentially means the collapse of the current political integrity (for example, the fall of the 
political regime, the dissolution of the party, state capture by external forces, etc.). In the scale of society such changes may indicate that the decisions regime less help him to effectively manage and regulate social relations, so that the regime loses its existence sufficient for the stability and legitimacy of the [12, p. 16].

\section{Features of the political process}

Coinciding in scale with the entire political space, a political process is not limited to conventional (contractual, regulatory) changes that characterize the behavioral actions, relationships and mechanisms of competition for state power, meeting the norms accepted in the society and the rules of the political game. Along with these political processes and capture the changes that reveal a violation of the subjects of their roles and functions set forth in the regulatory framework, abuse their powers, going beyond their political niche. Thus, the content of the political process in the fall and the changes that take place in the activity of subjects who do not share a common standard in the relationship with the government, for example, the activities of the parties in an irregular situation, terrorism, criminal acts of politicians in power, etc.

Reflecting really developed, not only the planned changes, the political process have a pronounced non-normative nature, which can be explained by the presence in the political space of various types of movement (wave, cyclic, linear, inversion, ie return, and others.) That have their own forms and methods of transformation of political phenomena, the combination of which deprives the latter of strict certainty and stability [2, p. 123].

From this perspective, the political process is a set of relatively independent, local transformations of the political activity of subjects (relationship, institutions) that occur at the intersection of a variety of factors and parameters which can not be accurately determined, and furthermore predicted. This political process is characterized by discrete 
changes or the ability to modify some parameters of the phenomenon and at the same time preserving intact his other traits and characteristics (for example, changing the composition of the government can be combined with the preservation of the old policy). The unique and discrete changes exclude the possibility of extrapolation (transferring values of modern facts for the future) of certain assessments of the political process, complicates political forecasting, foresight puts limits political prospects.

At the same time, each type of policy change has its own rhythmic (cyclical repetition), a combination of steps and interactions of subjects, organizations, institutions. For example, the electoral process is formed in connection with the election cycles, so the political activity of the population is developing in accordance with the phases of the nomination of candidates in the legislative or executive bodies, discussing their candidates, election and control over their activities. Own Rhythm political processes can define decisions of the ruling parties. In the same period the qualitative reformation of public relations decisive influence on the functioning of public institutions and ways of political participation of the population have no solution of higher authorities, and some political events that change the balance and the balance of political forces. Such a «ragged» rhythm can set the political process, military coups and international crises, natural disasters, etc.

Reflecting the real, practical changes in the prevailing political phenomena, political process necessarily includes in its content and the relevant technology and action procedure. In other words, the political process demonstrates the nature of the changes, which is associated with the activity of a specific subject, is used in a particular time and in a particular place for him habitual ways and means of action. Therefore, the use of different technologies, even solutions of the homogeneous problems requires different changes in character. Thus, without this level of technocratic policy changes become abstract, losing its specificity and concrete historical design. 


\section{The regional dimension of cultural policy. In the works of Ukrainian researchers found several options to define the cultural policy.}

In a broad sense, cultural policy is seen as a set of principles and standards, as well as a system of measures for the preservation, revitalization, development and expansion of the culture through a variety of state and public institutions. In a narrow sense, cultural policy - a state activity in the sphere of culture [13, p. 8].

Under the policy is a cultural activity of the representatives of various social circles, aimed at the formation of creative activity of the subject, the definition of the boundaries and conditions of work, selection, organization created cultural values, their coverage and consumption to achieve the objectives of the data subject, the most important of which are the reproduction of the existing system of social and political relations [14, p. 12].

Based on the above, the concept of cultural policies in the region (Donbass) can be defined as a set of anti-crisis measures at the national and regional level, aimed at regulating the activities of the subjects of the cultural life of the region, as well as processes that are aimed at the restoration and further development of the culture of the region during the transitional period.

It should be noted that cultural policy is a socio-cultural process governing relations between members of society, where regulators will act as norms of behavior.

State cultural policy must necessarily be paternalistic, but it can not be seen as charity, it is the duty of the state, it must focus not only on today's cultural needs of the population, but also take into account the long-term public interest in this area. Meritornaya State practice aimed at the formation and promotion of lagging demand "desired company", therefore, the concept of regulation of the population of consumer culture is well within the scope of the positional Enlightenment cultural policy and its objective: the creation of a field for a free and creative self-realization [15, p. 14]. 
Given the transition of Donbass and radical social transformation in this territory, the process of developing cultural policy is of paramount importance in the preparation of anti-crisis strategic plan for development of the region, since the quality of the cultural policy will depend on the ability of society and a measure of perception of political and administrative reforms and social transformations.

Implementation of modern cultural policy involves consideration of a number of principles, namely:

- Presence in the organization, which is involved in the political process, own position on the relationship of politics and culture;

- A permanent influence on the processes of relations with the state of politics and culture;

- Determination of priorities in the field of creativity and of the quality evaluation system of cultural products, which is a prerequisite for the implementation of cultural policies;

- An objective relationship between the degree of influence of the subject of cultural policy on the processes that occur in the field of culture and the amount of material resources attracted them;

- The dependence of the specifics of the implementation of the cultural policy of the social and political factors specific to the company $[14$, p. 13];

- Multiculturalism (processes, attitudes, politics and cultural diverse society based on freedom of expression, cultural experience, the definition of cultural diversity, cultural, ideological, political, religious pluralism, the definition of minority rights, both at the public and at the state level, tolerance);

- Cultural democracy;

- Attracting cultural identity in case of failure of the self-imposition;

- The preservation and development of linguistic diversity;

- Focus on the development of cultural policy creation;

- Focus both on national and universal values; 
- Determination of the priority of international legal acts in the sphere of culture [16, p. 15].

If we talk about the Donbass during the transitional period, this list may be supplemented by the following principle of modern cultural policy:

- The unity of the information field in the region, which has a dramatic impact on the formation of the main directions of the cultural policy of the territory;

- Unity and integrity of the cultural space in the region;

- The personification of the cultural policy, that is, identifying the link between cultural processes and their developers.

Most scientists agree on the general opinion that cultural policy is one of the most important components of the sustainable development of a given territory, which is controlled by society as a whole and the State in particular.

Support and regulation of culture carries primarily society through local governments, private investment, donations, sponsorship, as well as the state itself through the redistribution of budget revenues, grants, investments at low interest rates, targeted funding, legal framework, counseling, information support.

Regional culture should be supported by resource capabilities, namely the formation of territorial (regional) cultural development fund. The region should be the main level at which the regulation of cultural life.

The strategically important area of cultural policy should be Donbass protectionism and promoting cultural region of the platform, which will be based on an understanding of its weighty significance in the world, value and spiritual development of the individual.

The basis for the creation of a new system of legal regulation of the region's cultural policy should be a legal basis which will regulate philanthropy. Cultural policy Donbass needs to create a legal framework to promote initiatives in the field of philanthropy and supporting these initiatives. 
It should be understood that for a qualitative and efficient carrying out of cultural policies in the region of one of the state support is not enough. The state, in turn, creates only the external conditions for the cultural development. In this case, we have the following relationship: "the state - region - personality." That is, the state should create conditions for a cultural policy in the region, the region should provide opportunities for cultural development of the region's inhabitants, and every person is a carrier of the traditions of the region, and, therefore, is the basis for self-culture.

The cultural heritage of the Donbass is one of the forms of collective memory. Being in the zone of conflict, there is a risk of destruction of the unique resources of the region. Therefore, the cultural heritage of today requires special protection and attention. In this regard, it considered appropriate:

- To improve the mechanism of protection and conservation of the region's cultural heritage by: legal protection; financial and resource support of cultural institutions; development and implementation of comprehensive security plan and the preservation of cultural heritage; enhancing international cooperation in the field of cultural policy.

All of the above should be reflected in the development of the mechanism of protection of the cultural heritage of the region.

Detachment of the state of ill effects on the cultural sphere as well as the independence of the cultural institutions, their funding, and preferential tax support, financial and legal independence of the region - is the necessary steps for the improvement of cultural policies in the region.

\section{Conclusions}

Thus, the term "cultural policy" is one of those meaningful control which illustrates the nature of the cultural and civilizational processes in Ukraine. The official discourse of this phrase includes the 
variability of its realization. In particular, given the infrastructural and operational level to ensure the cultural policy in Ukraine, it can be perceived as a ritual formula, in the Soviet period had a certain ideological burden, and now - only symbolically reproduces the image of the state in the process of modeling a certain value paradigm. Given its scientific and theoretical support in existing concepts and programs have reason to conclude that the declaration of the state cultural policy intentions to modernize the system of spiritual values of society. And in fact, and in another case, the problem remains a degree of coincidence of culture content in projects of power and the practice of social activities. In fact, this is an attempt to combine the two strategies in a single formula. The choice in favor of modernization or kulturohranitelskimi draft cultural policy of the state can be caused as a strategic goal, and the presence of a specific mechanism for their implementation.

Therefore, the priority task of the region's cultural policy should be to create a new cultural infrastructure that will meet the requirements of the market economy, democracy and civil society. To do this: create an adequate existing legal framework of the cultural policy in the transitional development of the region; create non-state institutions of culture; to provide at the national level for the protection of cultural products through targeted taxation of its producers. These steps will contribute to the development of cultural industries in the region. Enhancing the region's cultural policy will not only have a positive socio-economic impact on the state as a whole, but also will contribute to the consolidation of civil society in the country.

\section{References}

1. Astaf'ev O.N. Sovremennaya nauka: Aktual'nye problemy teorii $i$ praktiki. Seriya «Gumanitarnye nauki». № 1-2. 2013.

2. Zhidkov V.S., Sokolov K.B. Kul'turnaya politika Rossii: teoriya i istoriya [Cultural Policy of Russia: Theory and History]. M., 2001. 
3. Tsybikov T.G. Vestnik Buryatskogo gosudarstvennogo universiteta. № 14. 2012.

4. Karpukhina O.I. Sotsial’no-gumanitarnye znaniya. 1999. № 4, pp. 60-73.

5. Karpukhin O.I. Kul'turnaya politika gosudarstva $v$ usloviyakh reformirovaniya obshchestva [The cultural policy of the state in the conditions of reforming society]. M., 1997.

6. Vostryakov L.E. Gosudarstvennaya kul'turnaya politika: ot paternalistskoy k partnerskoy modeli? // Upravlencheskoe konsul'tirovanie. 2011. № 4. S. 140-155.

7. Gorlova I.I. Kul'turnaya politika v usloviyakh perekhodnogo perioda: federal'nyy i regional'nyy aspekt [Cultural Policy in Transition: federal and regional aspects]. M., 1997.

8. Natochiy V.V. Kul'turnaya politika Rossii: problemy i perspektivy [Cultural Policy of Russia: problems and prospects]. Ufa: Bash. gos. univer., 2001. 158 p.

9. Bogatyreva T.G. Globalizatsiya i imperativy kul'turnoy politiki sovremennoy Rossii [Globalization and the imperatives of the cultural policy of modern Russia]. M., 2002.

10. Razlogov K.E., Orlova E.A., Kuz'min E.I. Otechestvennye zapiski. № 4 (25). 2005.

11. Skorodumova O.B. Znanie. Ponimanie. Umenie. 2008. № 4, pp. 40-44.

12. Balakshin A.S. Kul'tura i tsivilizatsiya: real'nost'i perspektivy razvitiya [Culture and Civilization: reality and prospects]. N. Novgorod: VGAVT, 1998, pp. 14-21.

13. Malimon V.I. Kul'turna politika derzhavi yak chinnik reformuvannya suspil'stva [Cultural politika powers yak chinnik reformuvannya suspilstva]. I.-F., 2011. 17 p.

14. Mikhaylovich V.A. Osnovni tendentsï kul'turnoï politiki v umovakh globalizatsiï [The main cultural policy trends in globalization]. K., 2010. 20 p.

15. Izhikova N.V. Teoretiko-metodologicheskie osnovaniya sovremennoy kul'turnoy politiki [Theoretical and methodological basis of modern cultural policy]. SPb., 2010. 20 p. 
16. Drozhzhina S.V. Kul'turna politika yak problema suchasnogo sotsiokul'turnogo protsesu [Cultural politika yak problem Suchasnyj sotsiokulturnogo Process]. D., 2004. 23 p.

17. Institut strategichnikh doslidzhen' "Nova Ukraïna» [Institute of Strategic Studies 'New Ukraine']. http://newukraineinstitute.org/about

18. Karpukhin O. I. Kul'turnaya politika i menedzhment [Cultural Policy and Management]. M.: In-t molodezhi, 1998. 174 p.

19. Kul'turna politika Ukraïni: natsional'na model' u evropeys'komu konteksti [Cultural Policy of Ukraine: national model in the European context] / S.I. Zdioruk, O.M. Litvinenko, O.P. Rozumna; za red. S.I. Zdioruka. K.: NISD, 2012. 64 p.

20. Flier A.Ya. Kul'turologiya dlya kul'turologov [Cultural Studies for cultural studies]. M.: Akademicheskiy proekt, 2000.

\section{DATA ABOUT THE AUTHORS \\ Lavryshsheva Maryna}

Donetsk StateUniversity of Management

157, Chelyuskintsev Str., Donetsk, 83015, Donetsk People's Republic

lavrimarina@yandex.ru

\section{Kozlova Liudmila}

Donbas National Academy of Civil Engineering and Architecture 2, Derzhavina Str., Makeevka, 86123, Ukraine Mila_pochta_84@mail.ru 